\title{
UGT1A1 wt Allele
}

National Cancer Institute

\section{Source}

National Cancer Institute. UGT1A1 wt Allele. NCI Thesaurus. Code C51018.

Human UGT 1A1 wild-type allele is located in the vicinity of $2 q 37$ and is approximately 13 $\mathrm{kb}$ in length. This allele, which encodes UDP-glucuronosyltransferase 1-1 protein, plays a role in the transformation of small lipophilic molecules into water-soluble metabolites. Certain allelic variants of the UGT 1A1 gene cause Crigler-Najjar syndrome type I, type II, Gilbert syndrome or transient familial neonatal hyperbilirubinemia. 